\title{
Absence of NEFL in patient-specific neurons in early-onset Charcot-Marie-Tooth neuropathy
}

Markus T. Sainio, MSc, Emil Ylikallio, MD, PhD, Laura Mäenpää, MSc, Jenni Lahtela, PhD, Pirkko Mattila, PhD, Mari Auranen, MD, PhD, Johanna Palmio, MD, PhD, and Henna Tyynismaa, PhD

Neurol Genet 2018;4:e244. doi:10.1212/NXG.0000000000000244

\section{Abstract}

\section{Objective}

We used patient-specific neuronal cultures to characterize the molecular genetic mechanism of recessive nonsense mutations in neurofilament light (NEFL) underlying early-onset CharcotMarie-Tooth (CMT) disease.

\section{Methods}

Motor neurons were differentiated from induced pluripotent stem cells of a patient with earlyonset CMT carrying a novel homozygous nonsense mutation in NEFL. Quantitative PCR, protein analytics, immunocytochemistry, electron microscopy, and single-cell transcriptomics were used to investigate patient and control neurons.

\section{Results}

We show that the recessive nonsense mutation causes a nearly total loss of NEFL messenger RNA (mRNA), leading to the complete absence of NEFL protein in patient's cultured neurons. Yet the cultured neurons were able to differentiate and form neuronal networks and neurofilaments. Single-neuron gene expression fingerprinting pinpointed NEFL as the most downregulated gene in the patient neurons and provided data of intermediate filament transcript abundancy and dynamics in cultured neurons. Blocking of nonsense-mediated decay partially rescued the loss of NEFL mRNA.

\section{Conclusions}

The strict neuronal specificity of neurofilament has hindered the mechanistic studies of recessive NEFL nonsense mutations. Here, we show that such mutation leads to the absence of NEFL, causing childhood-onset neuropathy through a loss-of-function mechanism. We propose that the neurofilament accumulation, a common feature of many neurodegenerative diseases, mimics the absence of NEFL seen in recessive CMT if aggregation prevents the proper localization of wild-type NEFL in neurons. Our results suggest that the removal of NEFL as a proposed treatment option is harmful in humans.

\author{
Correspondence \\ Dr. Tyynismaa \\ henna.tyynismaa@helsinki.fi
}

From the Research Programs Unit (M.T.S., E.Y., L.M., M.A., H.T.), Molecular Neurology, University of Helsinki; Clinical Neurosciences, Neurology (E.Y., M.A.), University of Helsinki and Helsinki University Hospital; Institute for Molecular Medicine Finland (FIMM) (J.L., P.M.), University of Helsinki; Neuromuscular Research Center (J.P.), Tampere University Hospital and University of Tampere; and Department of Medical and Clinical Genetics (H.T.), University of Helsinki, Finland.

Funding information and disclosures are provided at the end of the article. Full disclosure form information provided by the authors is available with the full text of this article at Neurology.org/NG. 


\section{Glossary}

CMT = Charcot-Marie-Tooth; INA = internexin; iPSC $=$ induced pluripotent stem cell; $\mathbf{m R N A}=$ messenger RNA; NCV = nerve conduction velocity; NEFH = neurofilament heavy; NEFL = neurofilament light; NEFM = neurofilament medium; NMD = nonsense-mediated mRNA decay; PRPH = peripherin; $\mathbf{q P C R}$ = quantitative PCR; UMI = unique molecular identifier.

Neurofilaments are 10-nm-wide intermediate filaments exclusive to neurons and crucial for the maintenance of neurite structure and integrity. ${ }^{1}$ Neurofilament light chain (NEFL) is among the core subunits of neurofilament, usually forming heterodimers with medium (NEFM) and heavy chains (NEFH), sometimes supplemented with either $\alpha$-internexin (INA) or peripherin (PRPH). The toxic accumulation of neurofilament is a hallmark of many neurodegenerative disorders, ${ }^{2-4}$ and thus, the removal of NEFL has been investigated as a treatment option. ${ }^{5}$ In addition, the potential of NEFL as a serum biomarker of neuronal injury in a number of neurologic disorders is currently investigated. $^{6-9}$

Gene mutations in NEFL have been found to underlie CharcotMarie-Tooth disease (CMT), either the demyelinating $\mathrm{CMT}_{1} \mathrm{~F}^{4}$ or axonal CMT2 $\mathrm{E}^{10}$ form. ${ }^{10,11}$ Most disease-causing NEFL mutations are dominantly inherited missense variants functioning through a gain-of-function mechanism, ${ }^{12,13}$ in which the missense mutant NEFL protein disrupts neurofilament assembly and organelle transport in the axons by forming aggregates. ${ }^{14,15}$ All reported recessive NEFL mutations have been homozygous nonsense variants. ${ }^{13,16,17}$ Elucidation of the disease mechanism of the recessive variants in humans has been complicated by the restricted neuronal expression of NEFL. ${ }^{18}$ Thus, it is not known if the homozygous nonsense variants cause disease through aggregation effects mediated by a truncated protein or by the loss of NEFL protein through nonsense-mediated messenger RNA (mRNA) decay (NMD). Here, we used patient-specific induced pluripotent stem cell (iPSC)-derived neuronal cultures and report that the complete absence of NEFL in patients with a homozygous NEFL nonsense mutation causes early-onset CMT.

\section{Methods}

\section{Standard protocol approvals, registrations, and patient consents}

Patient and control samples were taken according to the Declaration of Helsinki, with informed consent. The study was approved by the Institutional Review Board of the Helsinki University Hospital.

\section{Patients}

Two siblings, patients P1 and P2, now aged 30 and 27 years, respectively, who were born to healthy unrelated parents of Finnish origin, were investigated for motor and developmental delay in early childhood. The skin fibroblasts used in the study were derived from patient P1. Experimental details are described in the e-Methods (appendix e-1, links.lww.com/NXG/A54).

\section{Results}

\section{Clinical findings}

P1 was first examined as an infant because of nystagmus and tremor. Her feet were deformed resembling clubfoot, and her movements were clumsy. She learned to walk at the age of 20 months. Electrophysiology showed strongly decreased nerve conduction velocities (NCVs) corresponding to demyelinating sensorimotor neuropathy. At the age of 8 years, there was no response from the sensory median nerve. Ulnar sensory NCVs from the wrist to finger and the elbow to wrist were 9 and $19 \mathrm{~m} / \mathrm{s}$, respectively. Median and ulnar motor NCVs from the elbow to wrist were 21 and 16 $\mathrm{m} / \mathrm{s}$, respectively. The only response in the lower leg was recorded from tibialis anterior. Four years later, sensory NCVs were absent in all upper limb nerves (ie, radial, ulnar, and median). Median motor response was also absent, and ulnar NCVs were markedly reduced (ie, $11 \mathrm{~m} / \mathrm{s}$ from the elbow to wrist, no response from the wrist to finger). Needle examination showed denervation. There were unspecific mild white matter lesions on her brain MRI that were not progressive. Her younger brother, P2, had similar symptoms and electrophysiologic findings, although less severe, and his brain MRI was normal. During their school years, the patients were estimated to be approximately 2 years behind their peers in cognitive development. However, both managed to finish supported elementary school despite difficulties.

As neuropathy slowly progressed, distal muscle weakness became apparent in upper and lower extremities. Muscle atrophy was evident in the legs and intrinsic hand muscles. Both patients underwent orthopedic surgery for feet deformities and tight Achilles tendon. Distal weakness and waddling gait were observed. P2, aged 27 years, can still walk $50 \mathrm{~m}$ without aid, whereas P1 lost ambulation at the age of 25 years. For both patients, grip strength was reduced, pinching impossible, and fine motor skills decreased. Weakness in finger extension and flexion was severe (1-2/5 Medical Research Council [MRC $]$ scale). All movements were essentially lost in ankle plantar and dorsiflexion. There was also proximal muscle weakness in the upper and lower limbs but to a lesser extent (3-4/5 MRC). Tendon reflexes were absent. No clear sensory disturbances were found. In both patients, articulation was slow, but there were no dysarthria, facial weakness, or other bulbar symptoms. 
P1 was also diagnosed with ventricle septum defect in childhood and later aortic valve stenosis and regurgitation, sleep apnea, and severe obesity. The parents were healthy; both underwent electrophysiologic studies as part of their children's investigations with normal NCVs.

\section{Genetic findings}

Targeted next-generation sequencing panel for known CMT disease genes ${ }^{19}$ for the DNA sample of P1 revealed a novel homozygous c.1099C > T (g.24811765C>T) variant in exon 2 of the NEFL gene, predicting a nonsense change p.Arg367*. The patients were homozygous for the variant, and parents were heterozygous carriers (figure 1A). The GnomAD ${ }^{20}$ database $(277,044$ alleles) lists 15 heterozygous carriers of the variant in Finland, indicating an enrichment of the variant with a carrier frequency of 0.00058 . The localization of the variant together with previously reported disease-causing variants in NEFL domains is summarized in figure $1 \mathrm{~B}$.

\section{Absence of NEFL in patient-specific cultured neurons}

To investigate the consequences of the NEFL nonsense variant, we differentiated patient-specific iPSC, reprogrammed from P1 skin fibroblasts, into neurons. Two iPSC clones were used from $\mathrm{P} 1$, and 1 clone each from 3 unrelated control iPSCs. We used the motor neuron differentiation protocol, modified from reference 21 as summarized in figure $2 \mathrm{~A}$. We verified the neuronal differentiation by quantitative PCR (qPCR) of microtubule-associated protein 2 (MAP2) and $\beta I I I-t u b u l i n(T U B B 3$ ) mRNA expression (figure 2B) and by immunocytochemistry with TUBB3 (TUJ1) and MAP2 antibodies (figure 2C). Approximately $90 \%$ of DAPI-positive cells were also MAP2 and/or TUJ1 positive in each imaged frame. To validate the motor neuronal identity of the differentiated neurons, we analyzed the expression levels of ISL LIM homeobox 1 (ISL1), motor neuron and pancreas homeobox 1 (MNX1), and acetylcholine transferase (CHAT) by qPCR (figure 2D). Although some variation was detected

Figure 1 Dominant and recessive missense and nonsense variants in neurofilament light (NEFL)

A
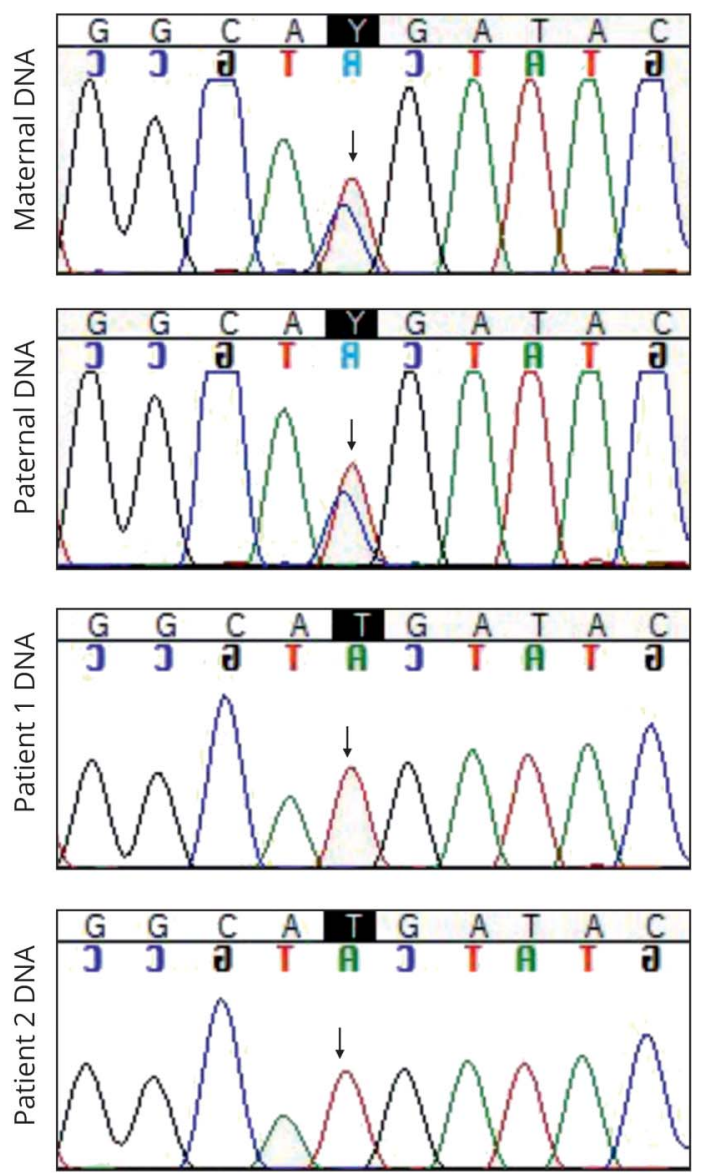

B

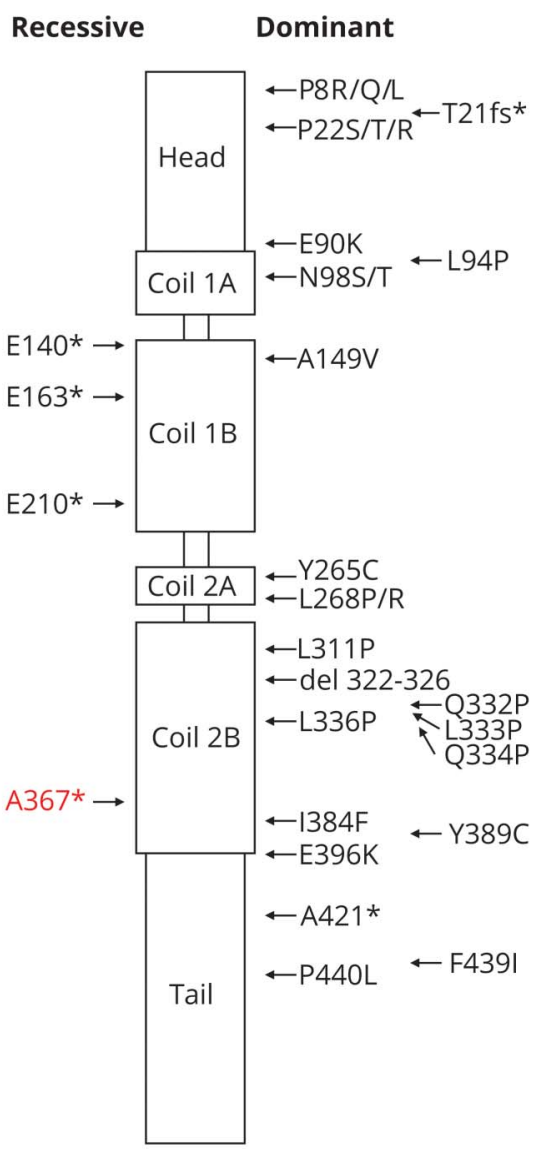

(A) Sequencing traces of the c.1099C>T variant in the family members show that both parents of the patients are heterozygous carriers of the mutation. (B) NEFL protein domains are depicted, and the localization of the reported missense and nonsense variants is indicated (modified from references 17 and 25 ). The nonsense variant $A 367 *$ identified in this study is shown in red. 
Figure 2 Neuron differentiation and validation
A

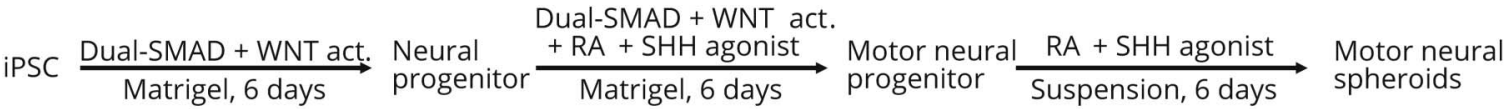
Motor neural $\longrightarrow \mathrm{RA}+\mathrm{SHH}$ agonist + Compound $\mathrm{E}+\mathrm{GF} \longrightarrow$ Motor neurons
spheroids PDL + Laminin, 12-20 days
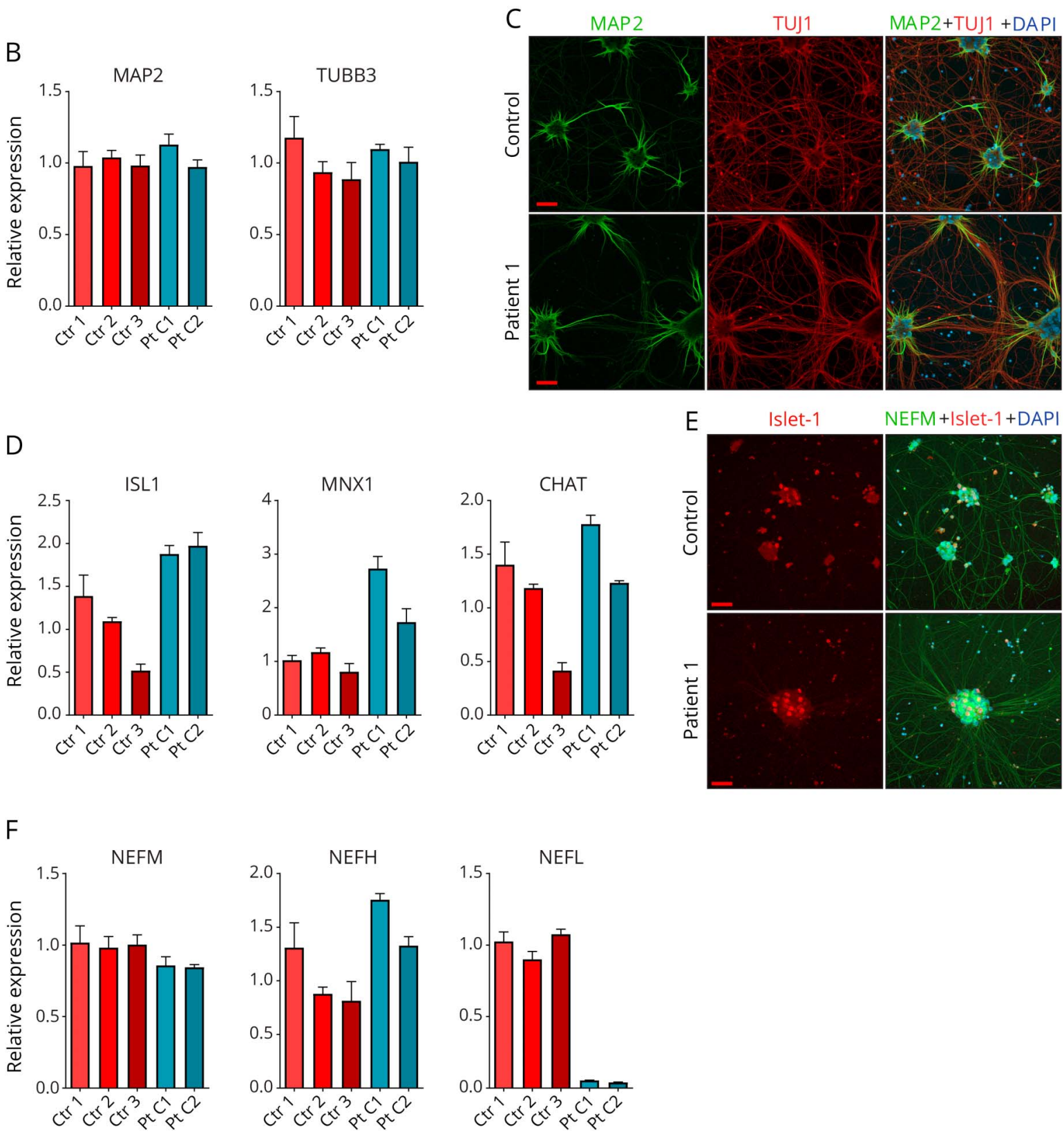

(A) Work-flow of fibroblast-derived induced pluripotent stem cell (iPSC) differentiation into motor neurons; Wnt signaling pathway activator (WNT act), retinoic acid (RA), Sonic hedgehog (SHH), growth factors (GF; BDNF, IGF-1 and CNTF), Poly-D-lysine (PDL). (B) Validation of the expression of neural transcripts MAP2 and TUBB3 against GAPDH by quantitative PCR (qPCR) in total culture RNA of patient 1 clones 1 (Pt C1) and 2 (Pt C2) and controls 1-3 (ctr 1-3) after motor neuron differentiation. (C) Immunocytochemical analysis of MAP2 (green) and TUBB3 (red) proteins in patient 1 and control neuronal cultures. (D) Validation of the expression of motor neural transcripts ISL1, MNX1, and CHAT by qPCR as in B. (E) Immunocytochemical analysis of ISL1 (red) and NEFM (green) protein in patient 1 and control neuronal cultures. ISL1-positive neurons are shown in larger cell clusters in the final differentiation stage (day 14 of in PDL + laminincoated plates). (F) Expression of intermediate filament subunits neurofilament medium (NEFM), neurofilament heavy (NEFH), and neurofilament light (NEFL) by $\mathrm{qPCR}$ as in $\mathrm{B}$. The bars in each graph represent mean levels $\pm S D, n=3$ for each cell line. All scale bars $50 \mu \mathrm{m}$. 4',6-diamidino-2-phenylindole (DAPI) indicates nuclear staining. 
between the different clones for the motor neuron markers, no decrease in differentiation potential was observed in patient lines in comparison with control lines. ISL1 expression was confirmed by immunocytochemistry in the neuronal cultures (figure 2E).

We then analyzed the mRNA levels of NEFL, NEFM, and $N E F H$ and observed that the patient neuronal cultures had a markedly decreased NEFL mRNA, with a residual level of about $5 \%$ in patient vs control samples, whereas patient NEFM and NEFH mRNA levels were comparable with control levels (figure 2F). This suggested that the nonsense mutant NEFL transcript was degraded by NMD. We next investigated whether NEFL protein could be detected in patient neurons by immunoblotting or immunocytochemistry. Relatively, even neuronal differentiation of lysed samples was validated by immunoblotting for TUJ1, NEFM, and CHAT proteins (figure 3A). The NEFL nonsense variant had predicted a potential C-terminally truncated protein of 366 amino acids (approximately $45 \mathrm{kDa}$ ). However, the Western blots of patient neuron lysates showed no full-length NEFL polypeptide $(68 \mathrm{kDa})$ or signs of a truncated NEFL protein using either an $\mathrm{N}$-terminal monoclonal (recognizing residues $6-25$ ) or a polyclonal pan-NEFL antibody (figure $3 \mathrm{~A}$ ), indicating that patient neurons were absent of NEFL. Using immunocytochemistry, highly similar neurite structures and neuronal networks were seen in patient and control motor neurons by NEFM immunostaining (figure 3B). The patient neurons did not show any staining with NEFL antibody, confirming that they were devoid of NEFL. However, they were still able to form as long, branching projections as the control neurons, suggesting that the intermediate filament network in the absence of NEFL was sufficient for axonal maintenance in culture.

\section{Intermediate filament transcript dynamics in cultured neurons}

To examine the gene expression fingerprints in single cultured neurons, we used the differentiated neuronal cultures of P1 clone 1 and control 1 for single-cell transcriptomics by the Macosko $^{22}$ method with 10X Genomics Single Cell Platform. ${ }^{23}$ After quality control, 1,336 cells could be profiled from P1 clone 1 and 418 cells from control 1 . The expression of 17,318 genes could be reliably detected in these cells. Clustering of the individual cells based on their transcriptome profiles resulted in 5 clusters. Neuronal cells clustered distinctly from other cells, driven by the expression of neuronspecific transcripts (figure 4A). Clustering revealed that $26.1 \%$ of the captured cells from P1 clone 1 (349 of 1,336 cells) and $23.0 \%$ from control 1 ( 96 of 418 cells) had a neural identity, depicted in $\mathrm{t}$-SNE projections colored by the expression of $M A P 2$, microtubule-associated protein tau (MAPT), growthassociated protein 43 (GAP43), and synaptophysin (SYP) (figure $4 \mathrm{~B})$. The captured neurons also expressed motor neuronal markers as depicted in figure $4 \mathrm{C}$ in which $C H A T$, SLC18A3, ISL1, MNX1, LHX1, LHX3, DCC, ONECUT1, and

Figure 3 Complete loss of neurofilament light (NEFL) protein in cultured patient neurons
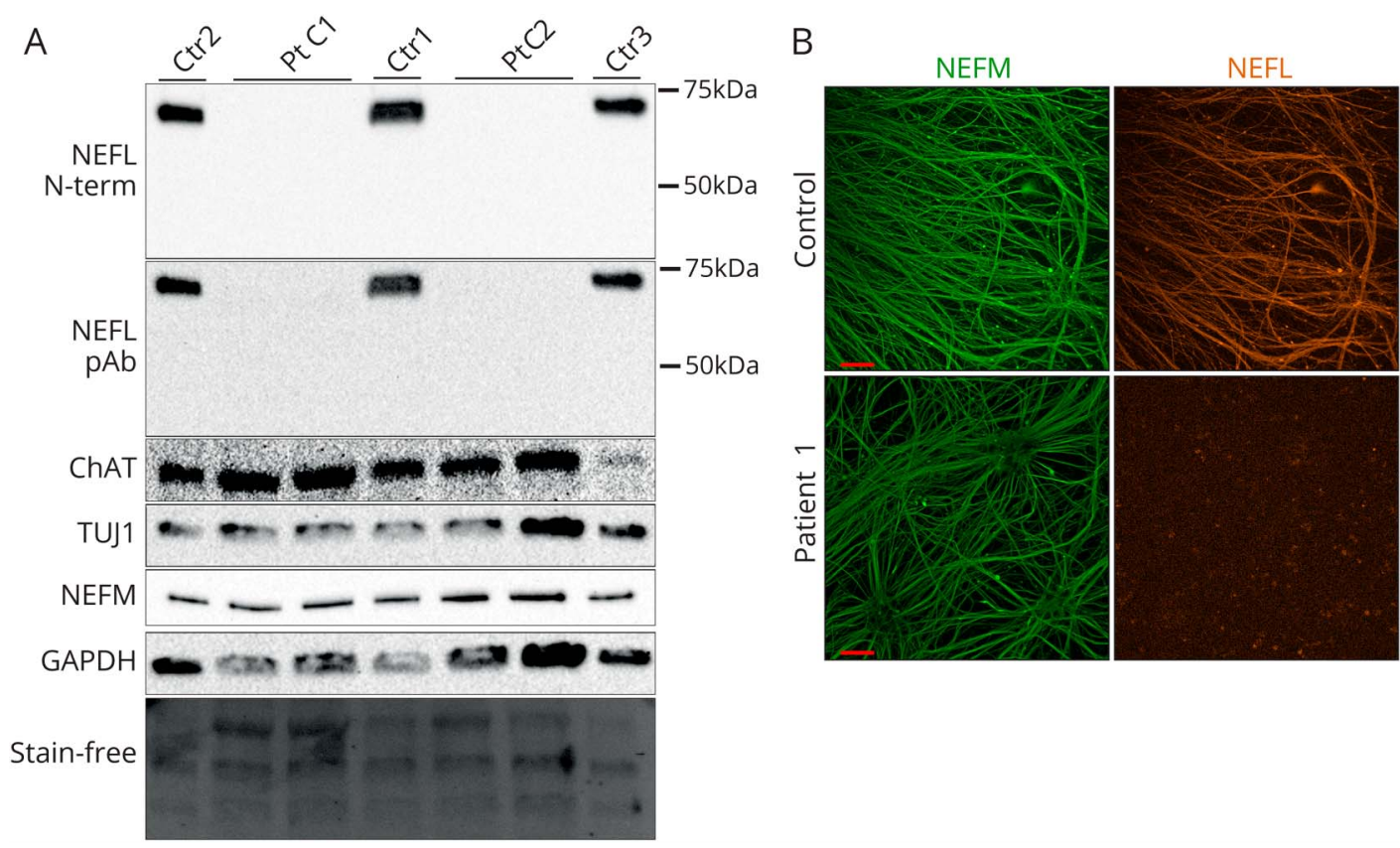

$\mathrm{NEFM}+\mathrm{NEFL}+\mathrm{DAP}$

(A) Immunoblotting of whole cell lysates of patient 1 clones 1 and 2 (Pt C1 and C2) and controls 1-3 (ctr 1-3) after motor neuronal differentiation with an Nterminal monoclonal or a polyclonal pan-NEFL antibody. Protein levels of neuronal markers ChAT, TUJ1, and neurofilament medium (NEFM) and the loading control glyceraldehyde 3-phosphate dehydrogenase (GAPDH) as well as the stain-free blot are shown. (B) Immunocytochemical analysis of NEFM (green) and NEFL (orange) of neurite architecture in patient 1 and control neurons after motor neural differentiation. 4',6-diamidino-2-phenylindole (DAPI) indicates nuclear staining. Scale bars $50 \mu \mathrm{m}$. 


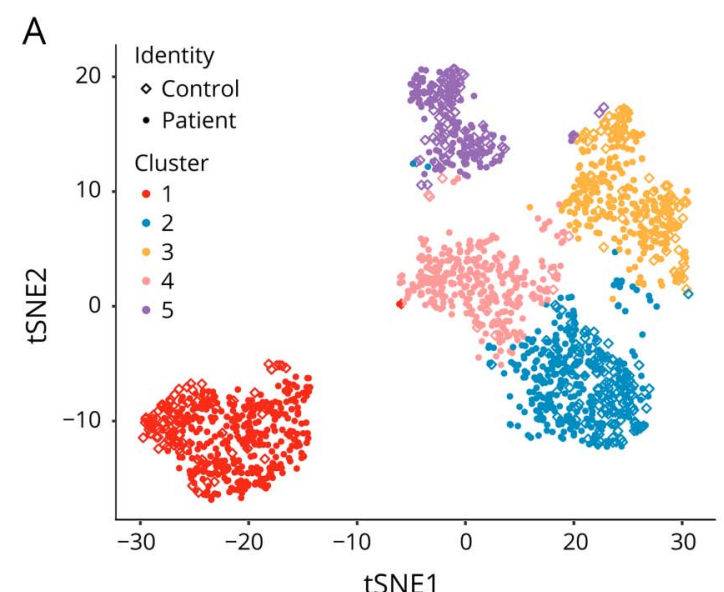

C summed motor neuron markers

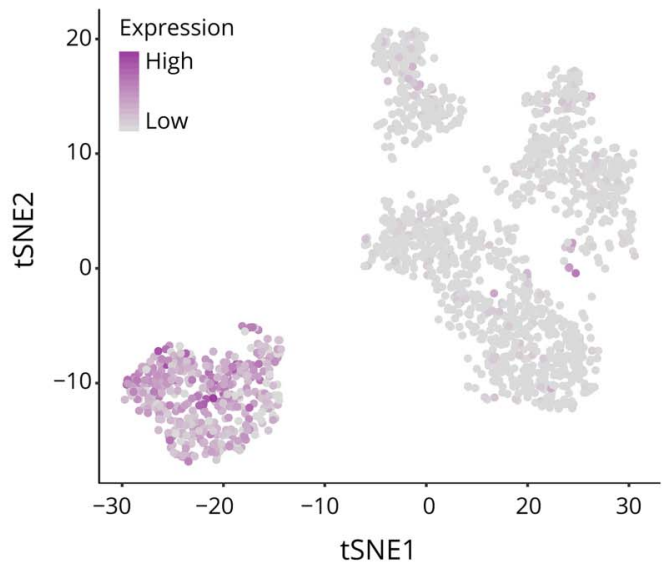

B
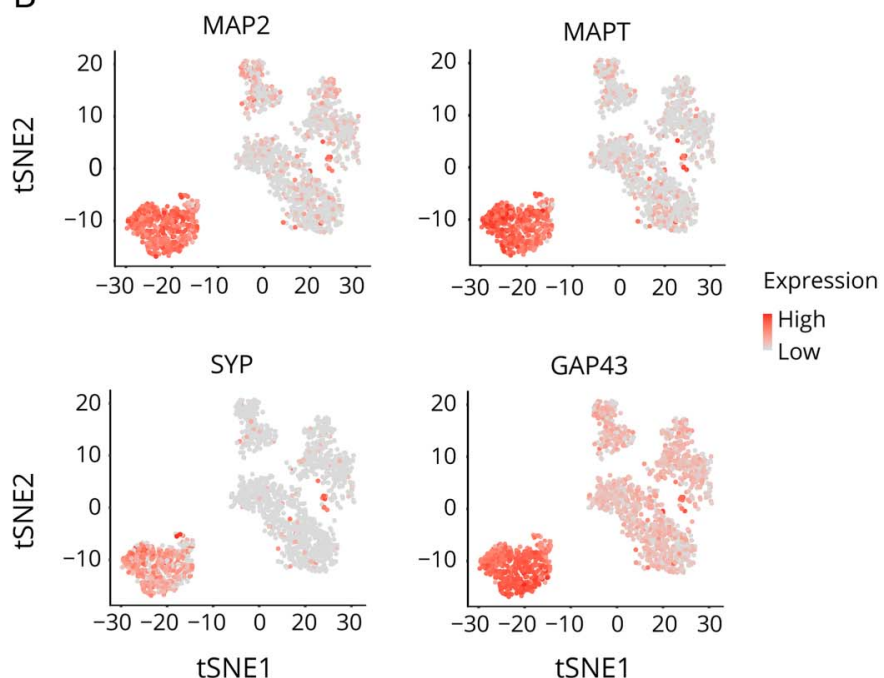

GAP43

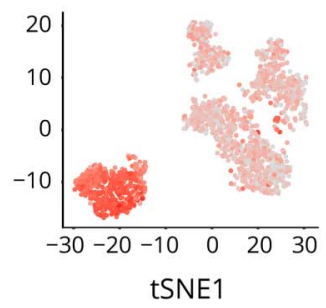

$\mathrm{E}$

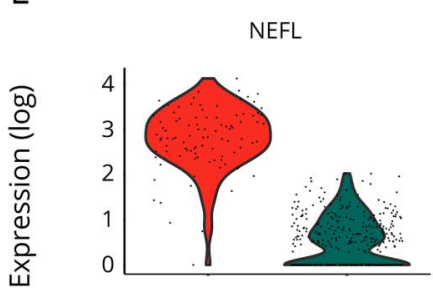

$\mathrm{NEFH}$

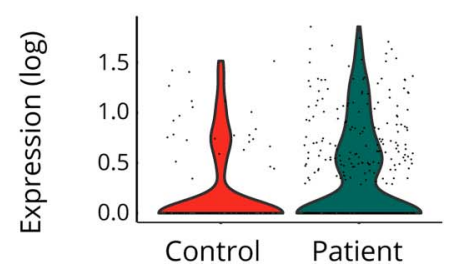

VIM

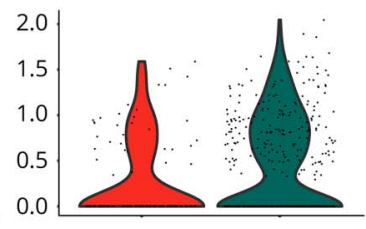

INA

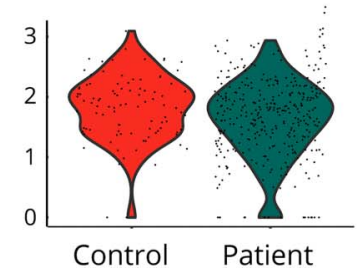

NEFM

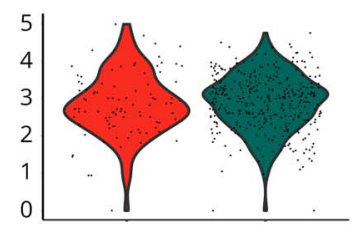

PRPH

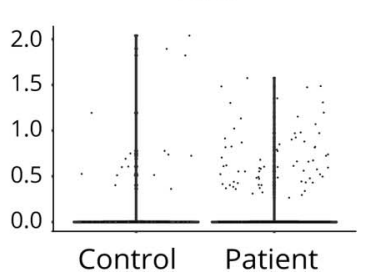

$\mathrm{F}$

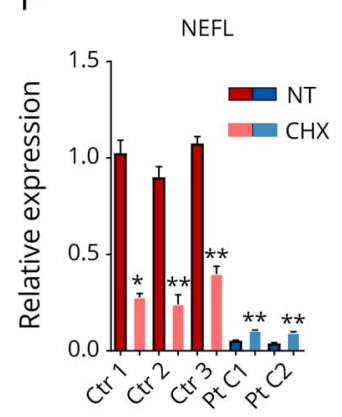

(A) Clustering of the single cells derived from patient 1 and control iPSCs in the tSNE-plot based on their gene expression fingerprints. Different clusters are color coded. In the combined single-cell sequencing data, patient cells are shown as filled dots and control cells as diamonds. Neurons are clustered as a clearly separate group of cells (cluster 1, red). (B) MAP2, MAPT, SYP, and GAP43 expression is high in the neuronal cluster cells. Red indicates high expression, and gray indicates low. (C) Cells in the neural cluster express motor neuron lineage-specific transcripts, CHAT, SLC18A3, ISL1, MNX1, LHX1, LHX3, DCC, ONECUT1, and ONECUT2, summed in the tSNE-plot. Purple indicates high expression, and gray indicates low. (D) The most significantly upregulated and downregulated transcripts (adjusted $p<0.001$ and absolute fold change $\geq 1.5$ ) in the neural cluster between patient and control cells. Neurofilament light (NEFL) is the most downregulated transcript in the patient neurons. (E) In the violin plots, each individual cell is shown with its specific transcript level, depicting the most downregulated transcript NEFL in patient neurons, and evenly expressed intermediate filament subunit transcripts INA, NEFM, NEFH, PRPH, and VIM. Expression refers to normalized log(e) expression scale. (F) Expression of NEFL against GAPDH by qPCR from total culture RNA of patient clones 1 (Pt C1) and 2 (Pt C2) and controls 1-3 (Ctr 1-3) after motor neuronal differentiation, nontreated (NT) or treated with $200 \mu \mathrm{g} / \mathrm{mL}$ cycloheximide (CHX) for 18 hours. The comparisons were made individually between each cell line with and without CHX treatment, $\mathrm{n}=3$ for each cell line and treatment (unpaired 2-tailed $t$ test, ${ }^{\star *} p<0.001,{ }^{*} p<0.01$ ). Bars represent mean levels \pm SD. 
ONECUT2 are summed, indicating that these neurons are part of the motor neuronal lineage. The neuronal differentiation efficiency in cultures was much greater than the percentage of captured neurons, which reflects the difficulty to capture neuronal cells with long extensions in contrast to morphologically more favorable cell types. However, large numbers of neurons were successfully captured from patient and control cultures, and the proportion of neuronal cells of all captured cells was comparable in patient and control data.

To gain an overall appreciation of the abundancy of the captured mRNAs per gene in the cultured neurons and of the ratios of the different intermediate filament transcripts, we analyzed the mean unique molecular identifier (UMI) counts for each gene in the control neuronal cell cluster. The most highly expressed gene was MALAT1 (metastasis associated lung adenocarcinoma transcript 1 ), followed by a number of genes for cytoskeletal proteins such as tubulin and actin, ribosome subunits, and mitochondrial-DNA encoded oxidative phosphorylation complex subunits (figure e-1, links.lww.com/ NXG/A51). NEFM was the most highly captured intermediate filament transcript (46th in abundance), closely followed by NEFL (66th), whereas INA (238), VIM (2,728), PRPH $(2,991)$, and $N E F H(3,456)$ were much less frequent (figure e-1). The UMI counts per gene thus indicated that both NEFL and NEFM were very highly expressed transcripts in control cultured neurons.

At a single-cell level, when comparing the autosomal transcript levels in the patient neurons with control neurons (adjusted $p<0.001$ and absolute fold change $\geq 1.5$ ), NEFL was the most significantly downregulated transcript (10-fold) in the patient neurons (figure 4D). Violin plots in figure $4 \mathrm{E}$ demonstrate the reduced level of NEFL transcripts in individual neurons of patient identity in comparison to control identity, whereas other intermediate filaments were not significantly altered, indicating no transcriptional compensation. Although we found no evidence of stable NEFL protein in cultured patient neurons, the violin plot in figure 4E shows that some neurons still expressed a low level of NEFL mRNA. To study NEFL transcript dynamics, we blocked NMD by treating the neuronal cultures with cycloheximide (CHX), an inhibitor of protein synthesis. CHX significantly increased the amount of nonsense NEFL mRNA in patient neuronal cultures, but at the same time, CHX dramatically decreased the amount of wild-type NEFL mRNA in control neurons (figure $4 F$ ). These results indicated that NMD machinery was responsible for the nonsense mRNA degradation but could not completely abolish it because of its high abundancy. In addition, the NEFL mRNA levels appear to be tightly regulated in relation to protein synthesis.

In this study, we did not investigate in detail the potential other transcriptional alterations that were associated with NEFL loss in patient's cultured neurons, as these findings require substantial additional studies. For example, urotensin
2 (UTS2), a small cyclic peptide shown previously to regulate intracellular calcium in rat spinal cord neurons, ${ }^{24}$ was the most upregulated gene in patient vs control neurons, but its expression profile showed high variation within the individual patient neurons (figure e-2, links.lww.com/NXG/A52). Therefore, its specific role in association with NEFL loss is not clear.

\section{Neurite architecture}

Because NEFL is believed to be a fundamental building block in the intermediate filament network of axons and dendrites, ${ }^{1}$ we examined neurites in our cultures. By immunocytochemistry, we did not detect defects in neurite morphology in the patient's cultured neurons in comparison with control neurites. The neurite signals for TUJ1, MAP2, and NEFM were not reduced in patient cell lines (figure e-3A, links.lww.com/NXG/A53). We also performed electron microscopic analysis to further examine neurite structure. Neurite areas varied in cross sections, from 7,000 to $170,000 \mathrm{~nm}^{2}$, but did not significantly differ between control and patient samples (figure e-3B). Unexpectedly, cross sections of patient neurites showed in addition to microtubules a clear presence of intermediate filaments (figure 5). We counted the percentages of neurite cross sections that contained microtubules or filament bundles and observed similar numbers in control and patient samples (figure e-3C). Furthermore, the longitudinal sections of patient neurites displayed no signs of neurofilament accumulation or abnormalities indicating dysregulation in the microtubule network or axonal transport. Collectively, these results showed that cultured human neurons can form neurofilaments and maintain axonal structure in the absence of NEFL.

\section{Discussion}

We describe here CMT1F patients with a novel homozygous nonsense mutation in NEFL, and demonstrate that the mutation leads to the absence of NEFL in patient-derived cultured neurons. Both patients had the disease onset at infancy and presented with severely reduced NCVs and slowly progressive distal muscle weakness in lower and upper extremities. The low NCVs suggested that myelin was lost in the peripheral neurons, but nerve biopsies were not available from the patients to investigate whether the reduced NCVs were due to the dramatic loss of axonal caliber in the absence of NEFL or the loss of myelin. Intermediate to severe reduction in NCVs has been previously reported in association with certain NEFL mutations. ${ }^{4,11}$ In addition to peripheral nerve involvement, both of our patients had mild intellectual disability possibly also resulting from the NEFL defect, since abnormalities in cognitive development have been previously reported in a few patients with dominant or recessive NEFL mutations. ${ }^{13,25}$

Recessively inherited NEFL nonsense mutations typically cause an early-onset CMT. ${ }^{13,16,17}$ Homozygous p.Glu140* mutation was described in 1 patient with gait disturbance and progressive muscle weakness since school age, ${ }^{16}$ p.Glu2 $10^{*}$ in 

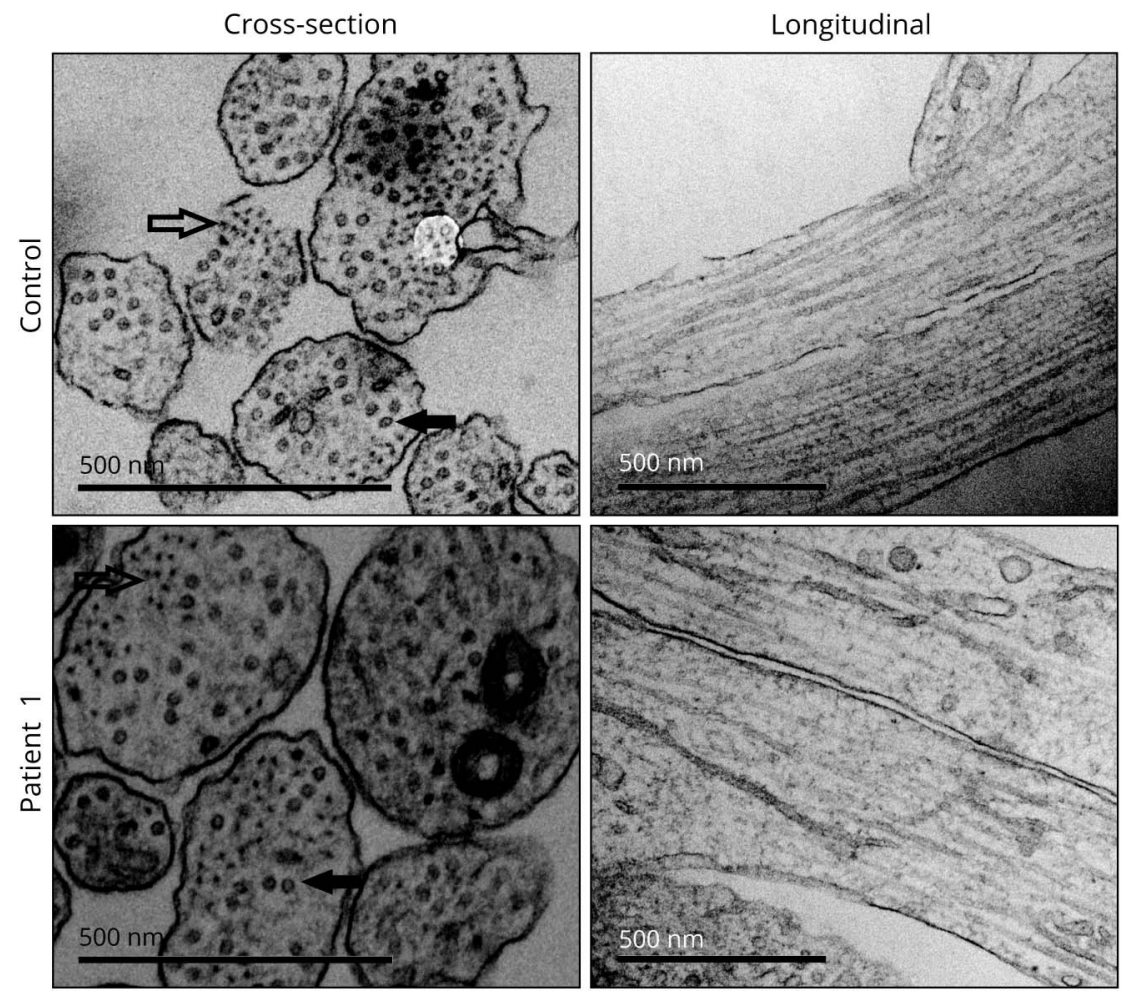

Representative electron microscopy images of neurite architecture in patient 1 and control neurons. Intermediate filaments (outlined arrow) and microtubules (filled arrow) are indicated in cross sections. Normal neurofilament network is seen in longitudinal sections of patient neurites. Scale bars $500 \mathrm{~nm}$.

4 siblings with slowly progressive distal muscle weakness and atrophy starting at approximately 1.5 years, ${ }^{13}$ and p.Glu163* in an adolescent girl with muscle weakness and gait disturbances during the first decade. ${ }^{17}$ Although neurofilament aggregation is well documented for dominant NEFL mutations, ${ }^{12,13,26}$ as well as in other neurodegenerative disorders, ${ }^{2,3}$ the molecular consequences of recessive nonsense mutations in NEFL have not been fully investigated. Neuronal specificity of NEFL has previously prevented studying the nonsense mutations in detail, and especially in cells with endogenous levels of mutant NEFL mRNA. Using neurons differentiated from patient-specific iPSC, we unexpectedly observed that the recessive NEFL nonsense mutation led to a complete absence of NEFL protein, through NMD of the nonsense mutant mRNA.

In this study, we demonstrate the loss of NEFL mRNA and protein in human neurons. In the literature, NEFL is largely considered as an essential component of neurofilament in mature neurons together with NEFM and NEFH. ${ }^{15}$ The composition of neurofilaments is also dependent on the neuronal type and developmental stage. ${ }^{15}$ Our single-neuron transcriptomics showed that NEFL and NEFM were highly abundant transcripts in the cultured neurons, whereas NEFH was not. Low NEFH transcript capture is consistent with its expression increasing only as a result of axonal maturation concomitant with myelination. ${ }^{27}$ INA and $\mathrm{PRPH}$ may also contribute to neurofilament formation, but are mostly expressed during early embryonic neuronal differentiation or in early postnatal brain, respectively, ${ }^{28,29}$ or following neuronal injury. ${ }^{30,31}$ In the cultured neurons of this study, we found the intermediate filaments expressed in the following order of abundance: NEFM $>$ NEFL $>$ INA $>$ VIM $>$ NEFH $>$ PRPH. In the patient neurons lacking NEFL, we found no indication of transcriptional compensation of other neurofilament polypeptides, although we could detect neurofilaments in the neurites by electron microscopy. This suggests that the intermediate filament formation in cultured neurons does not require NEFL. However, a recent study reported that a CMT patient with recessive NEFL nonsense mutations had no neurofilament in axons in a nerve biopsy as detected by electron microscopy. ${ }^{17}$ Combined with our demonstration of NEFL nonsense mutations leading to NEFL absence, their result indicates that in human peripheral axons, the lack of NEFL protein indeed leads to neurofilament loss. It is possible that the transport of neurofilaments to the long distal sural nerve may be impaired in patients, and this cannot be reproduced by the current in vitro model. It is important that the attempts to remove NEFL as a therapeutic intervention to its toxic accumulation ${ }^{5}$ should take into account that its loss is equally harmful to peripheral neurons and caused a severe early-onset disease in our patients. It is also noteworthy that the full Nefl mouse knockout only displayed a phenotype following nerve injury, ${ }^{32}$ suggesting major differences in the neurofilament biology between humans and mice, which may be connected to axon length.

Previous study of iPSC-derived neurons from CMT individuals carrying a NEFL missense variant found NEFL 
aggregate retention in the perikarya of neurons, possibly disrupting the neurofilament network and axonal maintenance. ${ }^{33}$ Our results indicate that CMT can be caused by both the loss of NEFL and its toxic accumulation. ${ }^{12}$ We therefore speculate that in the cases of NEFL accumulation, the toxicity is at least partly caused by the aggregates preventing the proper localization and function of wild-type NEFL, as well as disrupting the maintenance and turnover of intermediate filaments in the axon. This could result in NEFL loss in critical parts of the axons, similar to the situation in patients with recessive NEFL nonsense mutations. Indeed, reduced neurofilament has been detected in cutaneous nerve fibers of patients with dominant CMT2E, suggesting that aggregates in cell bodies led to neurofilament disruption distally. ${ }^{34}$

Here, we demonstrated that the absence of NEFL in human neurons causes early-onset CMT. As a limitation of our study, skin fibroblasts of only 1 patient from the family were available for iPSC generation. The lack of an obvious defect in neurofilament formation in cultured patient-specific neurons challenges the use of the current model system in studies of pathogenic mechanisms. In addition, we presented a case in which single-neuron transcriptomics could be used to identify the genetic defect based on the consequent gene expression alteration.

\section{Author contributions}

All authors acquired and analyzed data and contributed to the writing of the manuscript. M.T. Sainio, E. Ylikallio, J. Lahtela, P. Mattila, M. Auranen, and H. Tyynismaa designed the experiments. L. Mäenpää performed bioinformatic analysis. J. Palmio performed clinical investigations. E. Ylikallio and H. Tyynismaa supervised the study.

\section{Acknowledgment}

The authors thank Riitta Lehtinen for technical help. They acknowledge the Electron Microscopy Unit of the Institute of Biotechnology, University of Helsinki, for providing laboratory facilities and electron microscopy-sample preparation, and the Biomedicum Stem Cell Center, University of Helsinki, for iPSC generation and technical help.

\section{Study funding}

This work was supported by the Academy of Finland, Sigrid Juselius Foundation, University of Helsinki, Helsinki University Hospital, Doctoral Programme in Biomedicine, and Finska Läkaresällskapet.

\section{Disclosure}

Markus T. Sainio reports no disclosures. Emil Ylikallio has received research support from the Academy of Finland, University of Helsinki, and Emil Aaltonen Foundation. Laura Mäenpää, Jenni Lahtela, Pirkko Mattila. Mari Auranen, and Johanna Palmio report no disclosures. Henna Tyynismaa has served on the editorial board of Scientific Reports and has received research support from the Academy of Finland and
European Research Council. Full disclosure form information provided by the authors is available with the full text of this article at Neurology.org/NG.

Received January 17, 2018. Accepted in final form April 19, 2018.

\section{References}

1. Brown HG, Troncoso JC, Hoh JH. Neurofilament-L homopolymers are less mechanically stable than native neurofilaments. J Microsc 1998;191:229-237.

2. Hirano A, Nakano I, Kurland LT, Mulder DW, Holley PW, Saccomanno G. Fine structural study of neurofibrillary changes in a family with amyotrophic lateral sclerosis. J Neuropathol Exp Neurol 1984;43:471-480.

3. Israeli E, Dryanovski DI, Schumacker PT, et al. Intermediate filament aggregates cause mitochondrial dysmotility and increase energy demands in giant axonal neuropathy. Hum Mol Genet 2016;25:2143-2157.

4. Jordanova A, De Jonghe P, Boerkoel CF, et al. Mutations in the neurofilament light chain gene (NEFL) cause early onset severe Charcot-Marie-Tooth disease. Brain 2003;126:590-597.

5. Yadav P, Selvaraj BT, Bender FL, et al. Neurofilament depletion improves microtubule dynamics via modulation of Stat3/stathmin signaling. Acta Neuropathol 2016; 132:93-110.

6. Meeter LH, Dopper EG, Jiskoot LC, et al. Neurofilament light chain: a biomarker for genetic frontotemporal dementia. Ann Clin Transl Neurol 2016;3:623-636.

7. Disanto G, Barro C, Benkert P, et al. Serum neurofilament light: a biomarker of neuronal damage in multiple sclerosis. Ann Neurol 2017;81:857-870.

8. Weydt P, Oeckl P, Huss A, et al. Neurofilament levels as biomarkers in asymptomatic and symptomatic familial amyotrophic lateral sclerosis. Ann Neurol 2016;79: $152-158$.

9. Byrne LM, Rodrigues FB, Blennow K, et al. Neurofilament light protein in blood as a potential biomarker of neurodegeneration in huntington's disease: a retrospective cohort analysis. Lancet Neurol 2017;16:601-609.

10. Mersiyanova IV, Perepelov AV, Polyakov AV, et al. A new variant of Charcot-MarieTooth disease type 2 is probably the result of a mutation in the neurofilament-light gene. Am J Hum Genet 2000;67:37-46.

11. De Jonghe P, Mersivanova I, Nelis E, et al. Further evidence that neurofilament light chain gene mutations can cause Charcot-Marie-Tooth disease type 2E. Ann Neurol 2001;49:245-249.

12. Sasaki T, Gotow T, Shiozaki M, et al. Aggregate formation and phosphorylation of neurofilament-L Pro22 Charcot-Marie-Tooth disease mutants. Hum Mol Genet 2006;15:943-952.

13. Yum SW, Zhang J, Mo K, Li J, Scherer SS. A novel recessive nefl mutation causes a severe, early-onset axonal neuropathy. Ann Neurol 2009;66:759-770.

14. Gentil BJ, Minotti S, Beange M, Baloh RH, Julien JP, Durham HD. Normal role of the low-molecular-weight neurofilament protein in mitochondrial dynamics and disruption in Charcot-Marie-Tooth disease. FASEB J 2012;26:1194-1203.

15. Gentil BJ, Tibshirani M, Durham HD. Neurofilament dynamics and involvement in neurological disorders. Cell Tissue Res 2015;360:609-620.

16. Abe A, Numakura C, Saito K, et al. Neurofilament light chain polypeptide gene mutations in Charcot-Marie-Tooth disease: nonsense mutation probably causes a recessive phenotype. J Hum Genet 2009;54:94-97.

17. Fu J, Yuan Y. A novel homozygous nonsense mutation in NEFL causes autosomal recessive Charcot-Marie-Tooth disease. Neuromuscul Disord 2018;28:44-47.

18. Shy ME, Patzko A. Axonal Charcot-Marie-Tooth disease. Curr Opin Neurol 2011;24: $475-483$.

19. Ylikallio E, Johari M, Konovalova S, et al. Targeted next-generation sequencing reveals further genetic heterogeneity in axonal Charcot-Marie-Tooth neuropathy and a mutation in HSPB1. Eur J Hum Genet 2014;22:522-527.

20. Lek M, Karczewski KJ, Minikel EV, et al. Analysis of protein-coding genetic variation in 60,706 humans. Nature 2016;536:285-291.

21. Du ZW, Chen $\mathrm{H}$, Liu H, et al. Generation and expansion of highly pure motor neuron progenitors from human pluripotent stem cells. Nat Commun 2015;6:6626.

22. Macosko EZ, Basu A, Satija R, et al. Highly parallel genome-wide expression profiling of individual cells using nanoliter droplets. Cell 2015;161:1202-1214.

23. Zheng GX, Terry JM, Belgrader P, et al. Massively parallel digital transcriptional profiling of single cells. Nat Commun 2017;8:14049.

24. Filipeanu CM, Brailoiu E, Le Dun S, Dun NJ. Urotensin-II regulates intracellular calcium in dissociated rat spinal cord neurons. J Neurochem 2002; 83:879-884.

25. Horga A, Laura M, Jaunmuktane Z, et al. Genetic and clinical characteristics of NEFLrelated Charcot-Marie-Tooth disease. J Neurol Neurosurg Psychiatry 2017;88: 575-585.

26. Leung CL, Nagan N, Graham TH, Liem RK. A novel duplication/insertion mutation of NEFL in a patient with Charcot-Marie-Tooth disease. Am J Med Genet A 2006; 140:1021-1025.

27. Haynes RL, Borenstein NS, Desilva TM, et al. Axonal development in the cerebral white matter of the human fetus and infant. J Comp Neurol 2005;484: 156-167.

28. Escurat M, Djabali K, Gumpel M, Gros F, Portier MM. Differential expression of two neuronal intermediate-filament proteins, peripherin and the low-molecular-mass neurofilament protein (NF-L), during the development of the rat. J Neurosci 1990; 10:764-784. 
29. Kaplan MP, Chin SS, Fliegner KH, Liem RK. Alpha-internexin, a novel neuronal intermediate filament protein, precedes the low molecular weight neurofilament protein (NF-L) in the developing rat brain. J Neurosci 1990;10:2735-2748.

30. Beaulieu JM, Kriz J, Julien JP. Induction of peripherin expression in subsets of brain neurons after lesion injury or cerebral ischemia. Brain Res 2002;946:153-161.

31. Troy CM, Muma NA, Greene LA, Price DL, Shelanski ML. Regulation of peripherin and neurofilament expression in regenerating rat motor neurons. Brain Res 1990;529: 232-238.
32. Zhu Q, Couillard-Despres S, Julien JP. Delayed maturation of regenerating myelinated axons in mice lacking neurofilaments. Exp Neurol 1997;148: 299-316.

33. Saporta MA, Dang V, Volfson D, et al. Axonal Charcot-Marie-Tooth disease patientderived motor neurons demonstrate disease-specific phenotypes including abnormal electrophysiological properties. Exp Neurol 2015;263:190-199.

34. Pisciotta C, Bai Y, Brennan KM, et al. Reduced neurofilament expression in cutaneous nerve fibers of patients with CMT2E. Neurology 2015;85:228-234. 


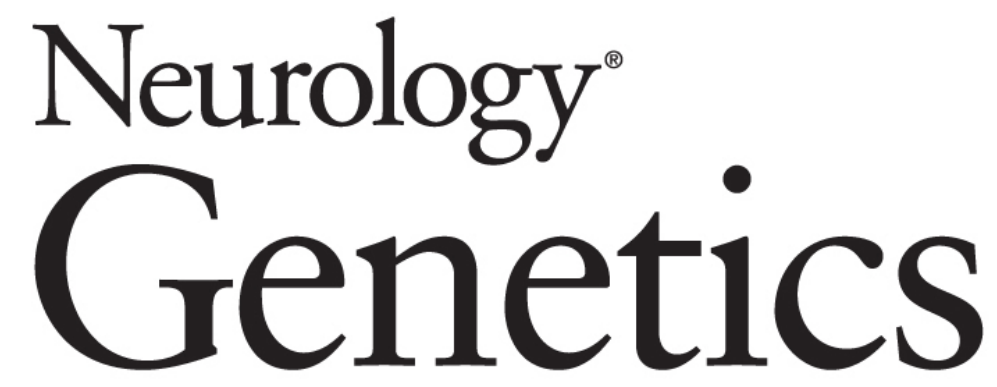
Absence of NEFL in patient-specific neurons in early-onset Charcot-Marie-Tooth neuropathy
Markus T. Sainio, Emil Ylikallio, Laura Mäenpää, et al. Neurol Genet 2018;4;
DOI 10.1212/NXG.0000000000000244

This information is current as of June 5, 2018

Neurol Genet is an official journal of the American Academy of Neurology. Published since April 2015, it is an open-access, online-only, continuous publication journal. Copyright Copyright $\odot 2018$ The Author(s). Published by Wolters Kluwer Health, Inc. on behalf of the American Academy of Neurology.. All rights reserved. Online ISSN: 2376-7839.

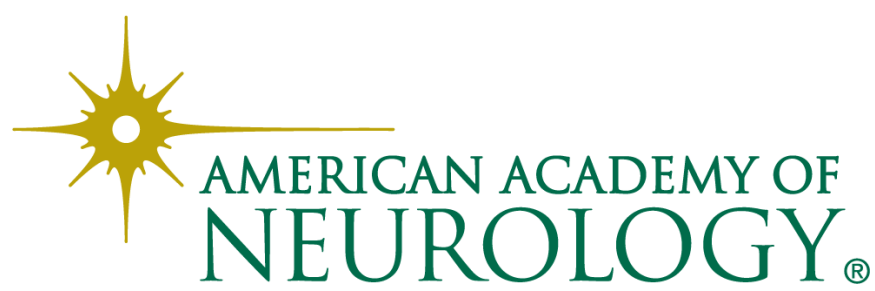




\section{Updated Information \& Services}

References

Citations

Subspecialty Collections

Permissions \& Licensing

Reprints including high resolution figures, can be found at: http://ng.neurology.org/content/4/3/e244.full.html

This article cites 34 articles, 3 of which you can access for free at: http://ng.neurology.org/content/4/3/e244.full.html\#\#ref-list-1

This article has been cited by 3 HighWire-hosted articles: http://ng.neurology.org/content/4/3/e244.full.html\#\#otherarticles

This article, along with others on similar topics, appears in the following collection(s):

\section{All Genetics}

http://ng.neurology.org//cgi/collection/all_genetics

Gene expression studies

http://ng.neurology.org//cgi/collection/gene_expression_studies

Peripheral neuropathy

http://ng.neurology.org//cgi/collection/peripheral_neuropathy

Information about reproducing this article in parts (figures,tables) or in its entirety can be found online at:

http://ng.neurology.org/misc/about.xhtml\#permissions

Information about ordering reprints can be found online:

http://ng.neurology.org/misc/addir.xhtml\#reprintsus

Neurol Genet is an official journal of the American Academy of Neurology. Published since April 2015, it is an open-access, online-only, continuous publication journal. Copyright Copyright $\odot 2018$ The Author(s). Published by Wolters Kluwer Health, Inc. on behalf of the American Academy of Neurology.. All rights reserved. Online ISSN: 2376-7839.

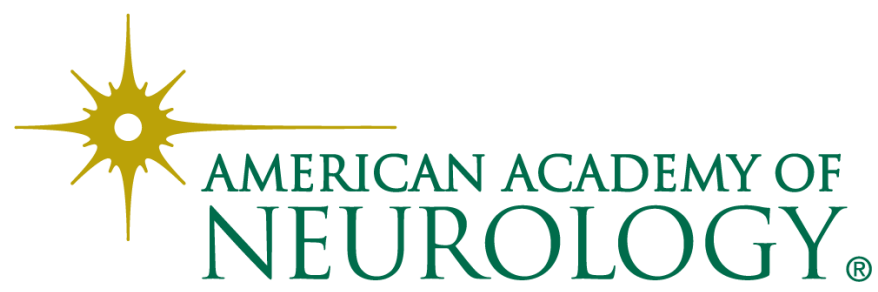

